\title{
Strategies of Nitrosomonas europaea 19718 to counter low dissolved oxygen and high nitrite concentrations
}

\author{
Ran Yu, Kartik Chandran*
}

\begin{abstract}
Background: Nitrosomonas europaea is a widely studied chemolithoautotrophic ammonia oxidizing bacterium. While significant work exists on the ammonia oxidation pathway of $\mathrm{N}$. europaea, its responses to factors such as dissolved oxygen limitation or sufficiency or exposure to high nitrite concentrations, particularly at the functional gene transcription level are relatively sparse. The principal goal of this study was to investigate responses at the whole-cell activity and gene transcript levels in N. europaea 19718 batch cultures, which were cultivated at different dissolved oxygen and nitrite concentrations. Transcription of genes coding for principal metabolic pathways including ammonia oxidation (amoA), hydroxylamine oxidation (hao), nitrite reduction (nirk) and nitric oxide reduction (norB) were quantitatively measured during batch growth, at a range of DO concentrations $(0.5,1.5$ and $3.0 \mathrm{mg} \mathrm{O} \mathrm{O}_{2} / \mathrm{L}$ ). Measurements were also conducted during growth at $1.5 \mathrm{mg} \mathrm{O}_{2} / \mathrm{L}$ in the presence of $280 \mathrm{mg}$ $\mathrm{N} / \mathrm{L}$ of externally added nitrite.

Results: Several wide ranging responses to DO limitation and nitrite toxicity were observed in N. europaea batch cultures. In contrast to our initial hypothesis, exponential phase mRNA concentrations of both amoA and hao increased with decreasing DO concentrations, suggesting a mechanism to metabolize ammonia and hydroxylamine more effectively under DO limitation. Batch growth in the presence of $280 \mathrm{mg}$ nitrite-N/L resulted in elevated exponential phase nirk and norB mRNA concentrations, potentially to promote utilization of nitrite as an electron acceptor and to detoxify nitrite. This response was in keeping with our initial hypothesis and congruent with similar responses in heterotrophic denitrifying bacteria. Stationary phase responses were distinct from exponential phase responses in most cases, suggesting a strong impact of ammonia availability and metabolism on responses to DO limitation and nitrite toxicity. In general, whole-cell responses to DO limitation or nitrite toxicity, such as sOUR or nitrite reduction to nitric oxide (NO) did not parallel the corresponding mRNA (nirk) profiles, suggesting differences between the gene transcription and enzyme translation or activity levels.

Conclusions: The results of this study show that $N$. europaea possesses specific mechanisms to cope with growth under low DO concentrations and high nitrite concentrations. These mechanisms are additionally influenced by the physiological growth state of $\mathrm{N}$. europaea cultures and are possibly geared to enable more efficient substrate utilization or nitrite detoxification.
\end{abstract}

\section{Background}

Nitrosomonas europaea is a widely studied chemolithoautotrophic ammonia oxidizing bacterium (AOB) that catalyzes the aerobic oxidation of ammonia $\left(\mathrm{NH}_{3}\right)$ to nitrite $\left(\mathrm{NO}_{2}{ }^{-}\right)$using carbon dioxide $\left(\mathrm{CO}_{2}\right)$ as the preferred assimilative carbon source [1]. Bacteria closely

* Correspondence: kc2288@columbia.edu

Department of Earth and Environmental Engineering, Columbia University, New York, NY 10027, USA related to $N$. europaea have been found in various natural and engineered environments indicating that they can proliferate under different growth conditions, by effectively utilizing growth substrates such as $\mathrm{NH}_{3}$ and oxygen [2-4].

The oxidative catabolic pathway of $N$. europaea involves $\mathrm{NH}_{3}$ oxidation to hydroxylamine $\left(\mathrm{NH}_{2} \mathrm{OH}\right)$ by membrane bound ammonia monooxygenase (AMO) and $\mathrm{NH}_{2} \mathrm{OH}$ oxidation to $\mathrm{NO}_{2}{ }^{-}$by periplasmic hydroxylamine

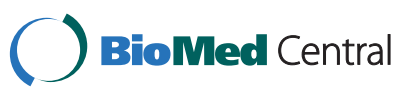




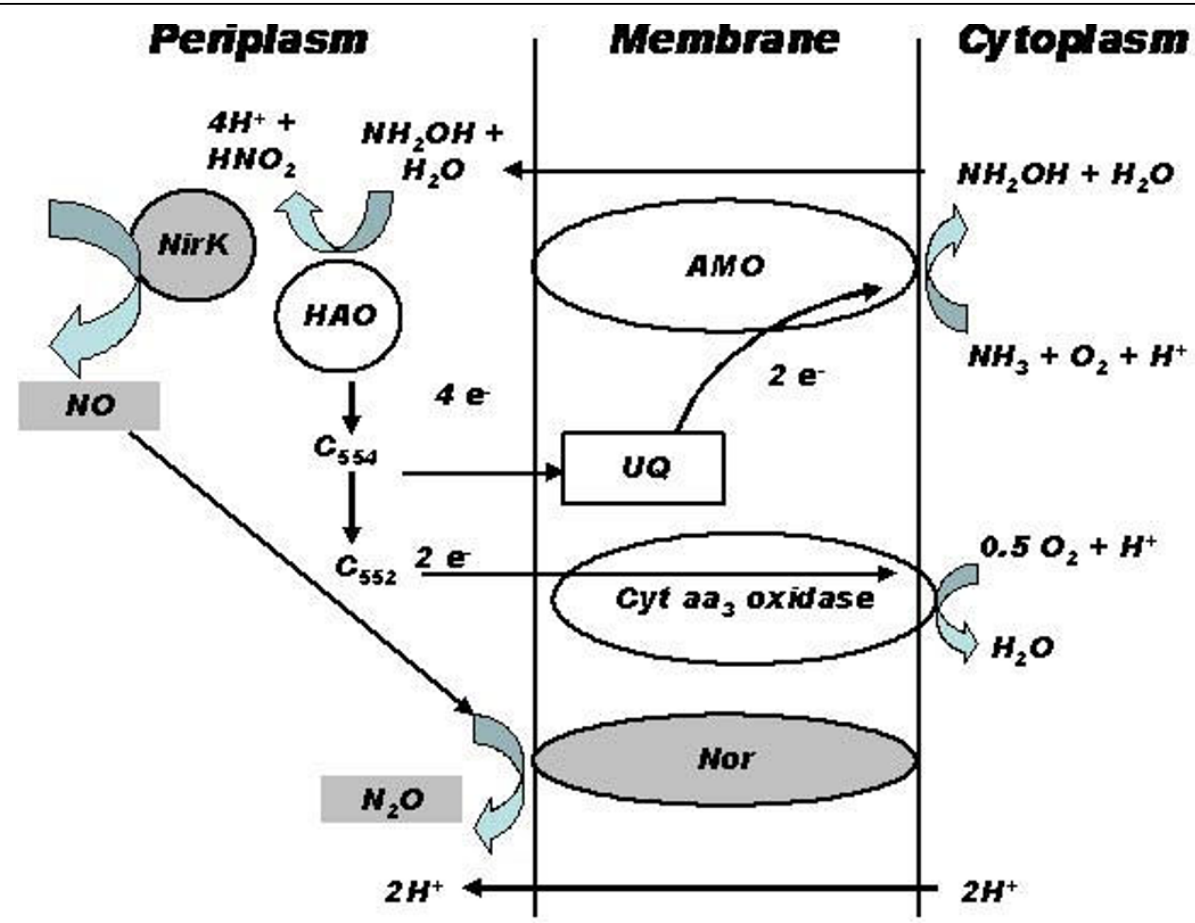

Figure 1 Schematic of oxidative (unshaded enzymes) and reductive (gray shaded enzymes) nitrogen transformations in $N$. europaea (modified after [5]).

oxidoreductase (HAO) (Figure 1) [5]. In addition, autotrophic denitrification by $N$. europaea has also been shown [6-8]. It is believed that denitrification by N. europaea is especially favored during growth under low dissolved oxygen (DO) concentrations or high nitrite concentrations [9] and results in the production of nitric oxide $(\mathrm{NO})$ or nitrous oxide $\left(\mathrm{N}_{2} \mathrm{O}\right)[10,11]$. However, little information exists on the mechanisms driving the responses of $N$. europaea to DO limitation and possible $\mathrm{NO}_{2}{ }^{-}$toxicity [12]. For instance, it is as yet unknown whether responses to $\mathrm{DO}$ limitation and $\mathrm{NO}_{2}{ }^{-}$toxicity at the whole-cell level are ultimate manifestations of changes in gene transcription and expression.

In this study, the ability of $N$. europaea to transcribe four key genes involved in its catabolic pathway as a function of batch growth conditions $\left(\mathrm{NH}_{3}\right.$ sufficiency and starvation, $\mathrm{DO}$ limitation and $\mathrm{NO}_{2}{ }^{-}$toxicity) was evaluated. It was hypothesized that DO limitation and $\mathrm{NO}_{2}{ }^{-}$toxicity would result in lower transcription of genes coding for $\mathrm{NH}_{3}$ and $\mathrm{NH}_{2} \mathrm{OH}$ oxidation (amoA and hao, respectively), given that these are the main steps leading to energy generation in N. europaea [5]. Furthermore, given that low $\mathrm{DO}$ and high $\mathrm{NO}_{2}{ }^{-}$concentrations are two main triggers for expression of denitrification genes in heterotrophic bacteria [13], it was hypothesized that decreasing DO concentrations and high $\mathrm{NO}_{2}{ }^{-}$concentrations would similarly induce progressively higher transcription of $\mathrm{NO}_{2}^{-}$and $\mathrm{NO}$ reductase genes in $N$. europaea (nirK and norB, respectively).

The specific objectives of this study were to (i) quantitatively measure the transcription of amoA, hao, nirK and $n o r B$, four genes involved in redox $\mathrm{N}$ transformations, in $N$. europaea during batch growth at different $\mathrm{DO}$ and initial $\mathrm{NO}_{2}{ }^{-}$concentrations; and (ii) compare gene transcription level responses to DO limitation and $\mathrm{NO}_{2}$ ' inhibition with 'whole-cell' responses related to activity, biokinetics and production of gaseous NOthe first product of sequential $\mathrm{NO}_{2}{ }^{-}$reduction by N. europaea.

\section{Results}

Impact of reactor DO on $\mathrm{N}$ speciation, biokinetics and functional gene transcription

Batch cultivation of $N$. europaea cultures at different DO concentrations $\left(0.5,1.5\right.$ and $\left.3.0 \mathrm{mg} \mathrm{O}_{2} / \mathrm{L}\right)$ led to several differences at the nitrogen speciation, biokinetics and gene transcription levels. Based on a studentized t-test, the degree of $\mathrm{NH}_{3}-\mathrm{N}$ conversion to $\mathrm{NO}_{2}{ }^{-}-\mathrm{N}$ at $\mathrm{DO}=0.5$ $\mathrm{mg} \mathrm{O}_{2} / \mathrm{L}(76 \pm 16 \%)$ was significantly lower $(\mathrm{p}<0.05)$ than at $\mathrm{DO}=1.5 \mathrm{mg} \mathrm{O}_{2} / \mathrm{L},(90 \pm 10 \%)$ or $\mathrm{DO}=3.0 \mathrm{mg}$ $\mathrm{O}_{2} / \mathrm{L}(89 \pm 15 \%)$, respectively, (Figure 2, A1-C1). The final cell concentrations were relatively uniform for all three DO concentrations (Figure 2, A2-C2). However, the lag phase at $\mathrm{DO}=0.5 \mathrm{mg} \mathrm{O}_{2} / \mathrm{L}$ was one day longer 


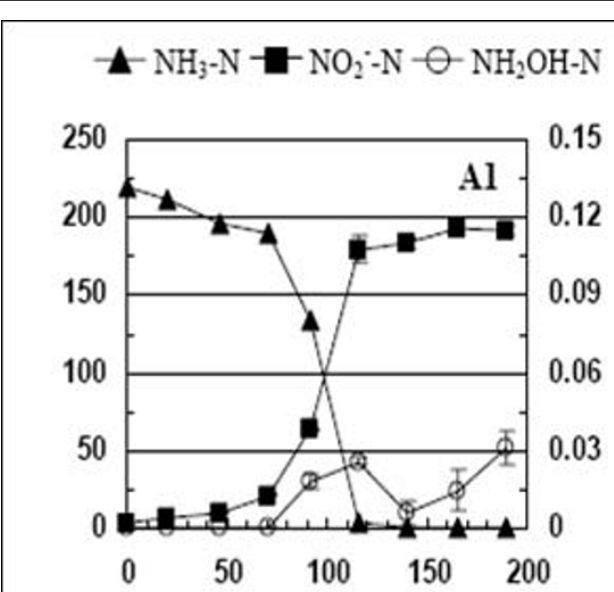

cell density - sOUR
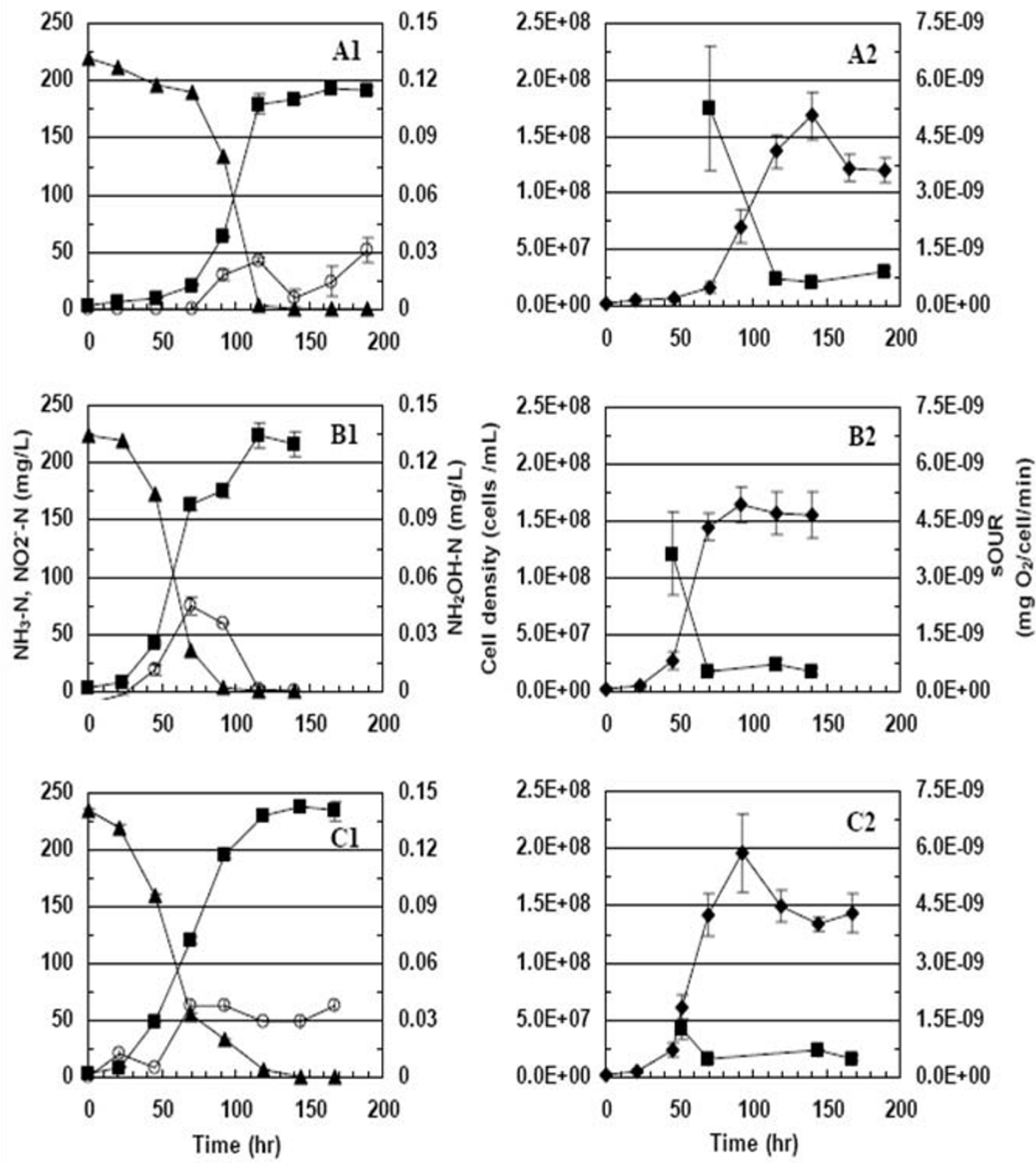

Figure $2 \mathrm{NH}_{3}-\mathrm{N}, \mathrm{NO}_{2}^{-}-\mathrm{N}$, and $\mathrm{NH}_{2} \mathrm{OH}-\mathrm{N},(\mathrm{A} 1-\mathrm{C} 1$ ), cell density and sOUR (A2-C2) profiles during $\mathrm{N}$. europaea batch growth at $\mathrm{DO}=0.5 \mathrm{mg} / \mathrm{L}(\mathrm{A}), 1.5 \mathrm{mg} / \mathrm{L}(\mathrm{B})$ and $3 \mathrm{mg} / \mathrm{L}(\mathrm{C})$.

than at $\mathrm{DO}=1.5$ or $3.0 \mathrm{mg} \mathrm{O}_{2} / \mathrm{L}$ pointing to the impact of electron acceptor limitation on the cell synthesizing machinery of $N$. europaea (Figure 2, A2-C2). Estimates of the maximum specific growth rate (obtained via nonlinear estimation [14] $)$ at $\mathrm{DO}=0.5 \mathrm{mg} \mathrm{O} / \mathrm{L}(0.043 \pm$ $\left.0.005 \mathrm{~h}^{-1}\right), 1.5 \mathrm{mg} \mathrm{O}_{2} / \mathrm{L}\left(0.057 \pm 0.012 \mathrm{~h}^{-1}\right)$ and $3.0 \mathrm{mg}$ $\mathrm{O}_{2} / \mathrm{L}\left(0.060 \pm 0.011 \mathrm{~h}^{-1}\right)$ were not statistically different at $\alpha=0.05$. At all three DO concentrations tested, low levels of $\mathrm{NH}_{2} \mathrm{OH}$ transiently accumulated in the growth medium during the exponential phase, in keeping with its role as an obligate intermediate of $\mathrm{NH}_{3}$ oxidation [5] (Figure 2, A1-C1). The initial increase in $\mathrm{NH}_{2} \mathrm{OH}$ concentrations at $\mathrm{DO}=0.5 \mathrm{mg} \mathrm{O}_{2} / \mathrm{L}$, was the slowest, due to the longer lag-phase (Figure 2, A1). The peak $\mathrm{NH}_{2} \mathrm{OH}$ concentration at $\mathrm{DO}=0.5 \mathrm{mg} \mathrm{O}_{2} / \mathrm{L}$ was also lower than at $\mathrm{DO}=1.5$ or $3.0 \mathrm{mg} \mathrm{O}_{2} / \mathrm{L}$ (Figure 2, A1-C1).

The peak 'potential' biokinetics of $\mathrm{NH}_{3}$ oxidation (expressed as SOUR, and measured under non-limiting 
DO and ammonia concentrations) varied inversely with reactor DO concentrations (Figure 2, A2-C2). sOUR values consistently peaked during early exponential growth phase followed by a significant decrease during stationary phase (Figure 2, A2-C2), in good correspondence with recent results [15]. Additional sOUR assays could not be conducted during the lag phase, owing to low cell concentrations, which would have consequently necessitated removal of excessively high sampling volumes.

Headspace NO concentrations peaked during the exponential phase and significantly diminished upon $\mathrm{NH}_{3}$ exhaustion in the stationary phase (Figure 3, A3-C3). An increasing trend in peak headspace NO concentrations was observed with increasing DO concentrations. NO formation was strictly biological and

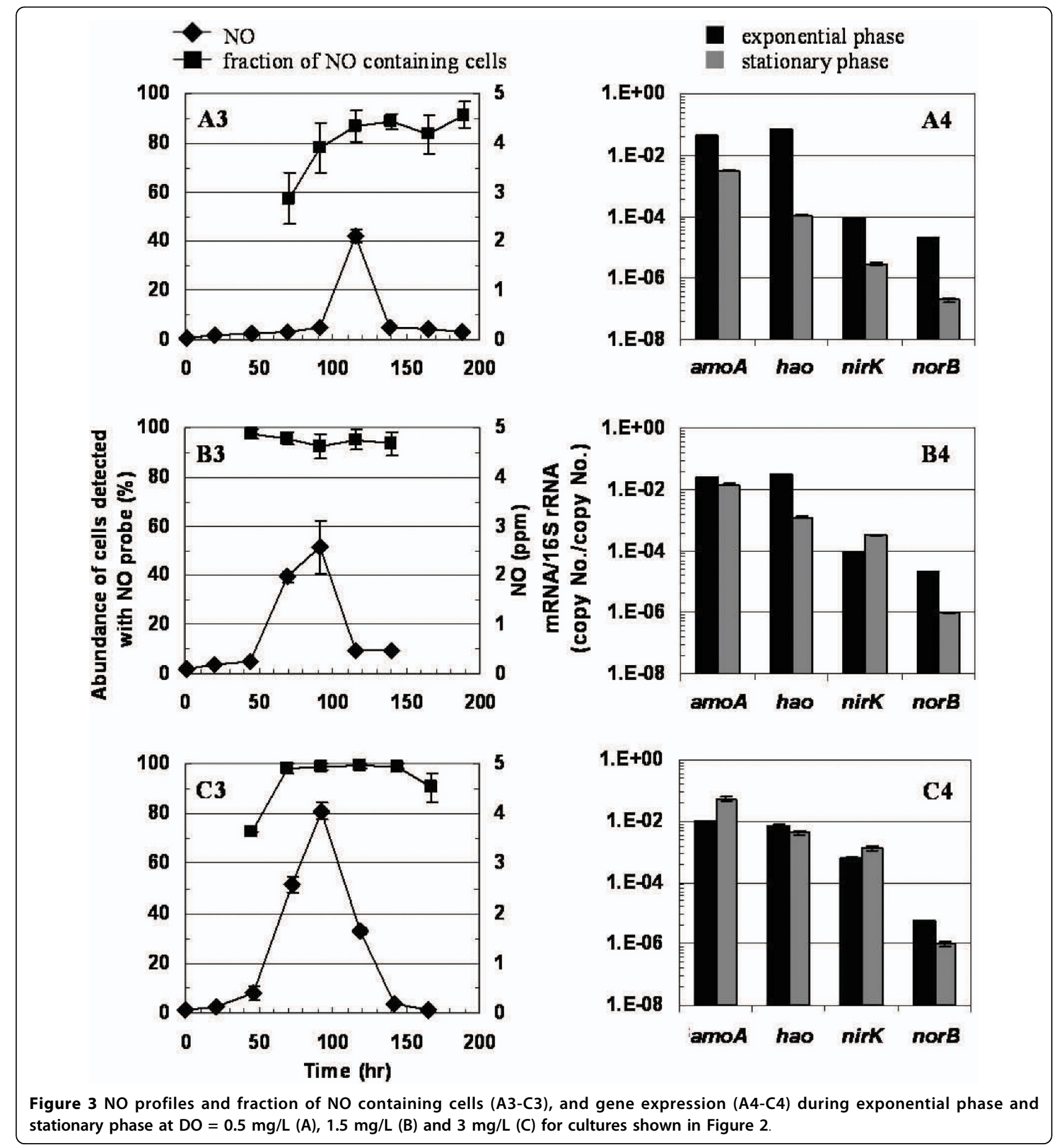


was not observed in cell-free controls (data not shown). At all DO concentrations tested, intracellular NO was detected in the majority of sampled cells (Figure 3 A3C3). NO 'positive' cell concentrations were highest especially during late exponential and stationary phases when $\mathrm{NO}_{2}{ }^{-}$, the likely substrate for $\mathrm{NO}$ production, concentrations were the highest (Figure 3 A3-C3). The more gradual increase in the proportion of $\mathrm{NO}$ positive cells at $\mathrm{DO}=0.5 \mathrm{mgO}_{2} / \mathrm{L}$ paralleled the trend in peak headspace NO concentrations (Figures 2, 3).

The impact of operating DO concentrations on gene transcript profiles, determined using primer sets described in Table 1, was dependent upon the physiological growth phase. In exponential phase cell samples, $a m o A$ and hao relative mRNA concentrations statistically decreased with increasing reactor DO concentrations (Figure 3, A4-C4, Table 2). A systematic impact of growth phase on nirK and norB relative mRNA concentrations was not observed during exponential phase. The relative mRNA concentrations for both genes during exponential phase were statistically similar for $\mathrm{DO}=0.5$ and $1.5 \mathrm{mg} \mathrm{O}_{2} / \mathrm{L}$ and statistically higher (for nirK) or lower (for norB) at DO $=3.0 \mathrm{mg} \mathrm{O} / \mathrm{L}$ (Figure 3, A4-C4, Table 2). In direct contrast, during stationary phase, the relative mRNA concentrations of amoA, hao and nirK all statistically increased with increasing DO concentrations. Additionally, the relative mRNA concentrations of nor $B$ at $\mathrm{DO}=1.5 \mathrm{mg} \mathrm{O} / \mathrm{L}$ were statistically higher than at $\mathrm{DO}=0.5 \mathrm{mg} \mathrm{O}_{2} / \mathrm{L}$, but statistically similar to those at $\mathrm{DO}=3.0 \mathrm{mg} \mathrm{O} / \mathrm{L}$ (Table 2).
At $\mathrm{DO}=0.5 \mathrm{mg} \mathrm{O}_{2} / \mathrm{L}$, the transition from exponential phase to stationary phase resulted in a systematic decrease in relative mRNA concentrations of all four genes (Figure 3A4-C4 and Table 3). At DO $=1.5 \mathrm{mg}$ $\mathrm{O}_{2} / \mathrm{L}$, this trend was valid for amoA, hao and norB. However, the stationary phase nirK relative mRNA concentrations were statistically higher than during exponential phase. At $\mathrm{DO}=3.0 \mathrm{mg} \mathrm{O}_{2} / \mathrm{L}$, only hao and nor $B$ displayed a decrease in relative mRNA concentrations upon transition from exponential to stationary phase (Figure 3A4-C4, Table 3). In contrast, relative mRNA concentrations of $a m o A$ and nirK increased during stationary phase (Figure 3A4-C4, Table 3). Additionally, except at $\mathrm{DO}=1.5 \mathrm{mg} \mathrm{O}_{2} / \mathrm{L}$ for nirK, the relative retention of $a m o A$ mRNA concentrations during stationary phase relative to exponential phase was consistently the highest (Figure 3 B4-C4). The retention factors averaged across all three DO concentrations were 1.98:1, 0.21:1, 1.86:1 and 0.08:1 for amo $A$, hao, nirK and nor $B$, respectively (where a retention factor $>1$ ) suggests relative increase during stationary phase).

\section{Impact of growth in the presence of added nitrite on $\mathrm{N}$ speciation, biokinetics and gene transcription}

Cell growth was not detected at an initial $\mathrm{NO}_{2}{ }^{-}$concentration of $560 \mathrm{mg}-\mathrm{N} / \mathrm{L}$ and $\mathrm{DO}=1.5 \mathrm{mg} \mathrm{O} / \mathrm{L}$, even after 2 weeks of incubation (data not shown). An initial $\mathrm{NO}_{2}{ }^{-}$concentration of $280 \mathrm{mg} \mathrm{NO}{ }^{-}{ }^{-} \mathrm{N} / \mathrm{L}$ and $\mathrm{DO}=$ $1.5 \mathrm{mg} \mathrm{O}_{2} / \mathrm{L}$, resulted in a lag phase one day longer

Table 1 Endpoint and real-time PCR primers employed in this study

\begin{tabular}{|c|c|c|c|c|}
\hline Primer & Sequence $\left(5^{\prime}-3^{\prime}\right)$ & Position & Target gene & Reference \\
\hline \multicolumn{5}{|c|}{ Endpoint PCR } \\
\hline $\begin{array}{c}\mathrm{A} 189 \\
\operatorname{amoA} 2 \mathrm{R}^{\prime}\end{array}$ & $\begin{array}{l}\text { GGHGACTGGGAYTTCTGG } \\
\text { CCTCKGSAAAGCCTTCTTC }\end{array}$ & $\begin{array}{l}151-168 \\
802-820\end{array}$ & $a m o A$ & {$[36,37]$} \\
\hline $\begin{array}{l}\text { HAO1F } \\
\text { HAO1R }\end{array}$ & $\begin{array}{l}\text { TCAACATAGGCACGGTTCATCGGA } \\
\text { ATITGCCGAACGTGAATCGGAACG }\end{array}$ & $\begin{array}{c}203-226 \\
1082-1105\end{array}$ & hao & {$[38]$} \\
\hline $\begin{array}{l}\text { NirK1F } \\
\text { NirK1R }\end{array}$ & $\begin{array}{l}\text { TGCTTCCGGATCAGCGTCATTAGT } \\
\text { AGTTGAAACCGATGTGGCCTACGA }\end{array}$ & $\begin{array}{c}31-54 \\
809-832\end{array}$ & nirk & {$[38]$} \\
\hline $\begin{array}{l}\text { NorB1F } \\
\text { NorB1R }\end{array}$ & $\begin{array}{c}\text { CGGCACTGATGTTCCTGTITGCTT } \\
\text { AGCAACCGCATCCAGTAGAACAGA }\end{array}$ & $\begin{array}{c}479-502 \\
1215-1238\end{array}$ & norB & {$[38]$} \\
\hline $\begin{array}{l}\text { KNO50F } \\
\text { KNO51R }\end{array}$ & $\begin{array}{l}\text { TNANACATGCAAGTCGAICG } \\
\text { GGYTACCTTGTTACGACTT }\end{array}$ & $\begin{array}{c}49-68 \\
1492-1510\end{array}$ & Eubacterial 165 rRNA gene & {$[39]$} \\
\hline \multicolumn{5}{|c|}{ Quantitative PCR } \\
\hline $\begin{array}{l}\text { amoAFq } \\
\text { amoARq }\end{array}$ & $\begin{array}{l}\text { GGACTTCACGCTGTATCTG } \\
\text { GTGCCTTCTACAACGATTGG }\end{array}$ & $\begin{array}{l}408-426 \\
524-543\end{array}$ & $a m o A$ & {$[15]$} \\
\hline $\begin{array}{l}\mathrm{HAO} 1 \mathrm{Fq} \\
\mathrm{HAO} 1 \mathrm{Rq}\end{array}$ & $\begin{array}{l}\text { TGAGCCAGTCCAACGTGCAT } \\
\text { AAGGCAACAACCCTGCCTCA }\end{array}$ & $\begin{array}{l}266-285 \\
331-350\end{array}$ & hao & {$[38]$} \\
\hline $\begin{array}{l}\text { NirK1Fq } \\
\text { NirK1Rq }\end{array}$ & $\begin{array}{l}\text { TGCAGGGCATACTGGACGTT } \\
\text { AGGTGAACGGGTGCGCATTT }\end{array}$ & $\begin{array}{l}182-201 \\
291-310\end{array}$ & nirk & {$[38]$} \\
\hline $\begin{array}{l}\text { NorB1Fq } \\
\text { NorB1Rq }\end{array}$ & $\begin{array}{l}\text { ACACAAATCACTGCCGCCCA } \\
\text { TGCAGTACACCGGCAAAGGT }\end{array}$ & $\begin{array}{c}958-977 \\
1138-1157\end{array}$ & norB & {$[38]$} \\
\hline $\begin{array}{l}\text { EUBF } \\
\text { EUBR }\end{array}$ & $\begin{array}{c}\text { TCCTACGGGAGGCAGCAGT } \\
\text { GGACTACCAGGGTATCTAATCCTGTT }\end{array}$ & $\begin{array}{l}339-357 \\
780-805\end{array}$ & Eubacterial $16 \mathrm{~S}$ rRNA gene & {$[34]$} \\
\hline
\end{tabular}


Table 2 Statistical comparison of the impact of DO concentrations on relative mRNA concentrations in exponential (E) and stationary $(S)$ phase cultures ( $p$ values $<5.0 \times 10^{-2}$ indicate statistically significant differences)

\begin{tabular}{|c|c|c|c|c|c|c|c|c|}
\hline \multirow{3}{*}{$\begin{array}{l}\text { DO } \\
\left(\mathrm{mg} \mathrm{O} \mathrm{O}_{2} / \mathrm{L}\right) \text { comparison }\end{array}$} & \multicolumn{8}{|c|}{$p=$} \\
\hline & \multicolumn{2}{|c|}{$a m o A$} & \multicolumn{2}{|c|}{ hao } & \multicolumn{2}{|c|}{ nirk } & \multicolumn{2}{|c|}{ norB } \\
\hline & $E$ & $S$ & E & $S$ & $E$ & $S$ & E & $S$ \\
\hline $0.5-1.5$ & $1.32 \times 10^{-4}$ & $1.64 \times 10^{-5}$ & $4.86 \times 10^{-5}$ & $3.3 \times 10^{-5}$ & $9.48 \times 10^{-1}$ & $2.9 \times 10^{-5}$ & $6.29 \times 10^{-1}$ & $4.63 \times 10^{-6}$ \\
\hline $1.5-3.0$ & $1.2 \times 10^{-5}$ & $1.98 \times 10^{-3}$ & $2.26 \times 10^{-11}$ & $2.16 \times 10^{-3}$ & $1.22 \times 10^{-5}$ & $1.78 \times 10^{-3}$ & $1.83 \times 10^{-7}$ & $7.52 \times 10^{-1}$ \\
\hline
\end{tabular}

Underlined text indicates statistically similar results, bold text indicates statistical increase and regular text indicates decrease.

Table 3 Statistical comparison of relative mRNA concentrations and sOUR in exponential and stationary phase cultures grown at different DO concentrations (p values $<5.0 \times 10^{-2}$ indicate statistically significant differences)

\begin{tabular}{cccccc}
\hline \multirow{2}{*}{$\begin{array}{c}\text { DO } \\
\left(\mathrm{mg} \mathrm{O}_{2} / \mathrm{L}\right)\end{array}$} & \multicolumn{5}{c}{$\mathrm{p}=$} \\
\cline { 2 - 6 } & amoA & hao & nirK & norB & sOUR \\
\hline 0.5 & $5.0 \times 10^{-5}$ & $1.1 \times 10^{-5}$ & $3.2 \times 10^{-6}$ & $8.0 \times 10^{-6}$ & $\underline{5.0 \times 10^{-1}}$ \\
\hline 1.5 & $5.5 \times 10^{-6}$ & $6.4 \times 10^{-8}$ & $7.7 \times 10^{-5}$ & $3.9 \times 10^{-6}$ & $1.5 \times 10^{-3}$ \\
\hline 3.0 & $1.5 \times 10^{-3}$ & $6.3 \times 10^{-4}$ & $5.1 \times 10^{-3}$ & $1.0 \times 10^{-6}$ & $\underline{1.2 \times 10^{-1}}$ \\
\hline
\end{tabular}

Underlined text indicates statistically similar results, bold text indicates statistical increase and regular text indicates decrease.

than that in the initial absence of nitrite (Figure 4 D1D2 and Figure 2, B1-B2, respectively). However, the overall cell yield was not impacted. The extent of $\mathrm{NH}_{3}$ oxidized to $\mathrm{NO}_{2}{ }^{-}$in the presence of $280 \mathrm{mg} \mathrm{NO}{ }^{-}-\mathrm{N} / \mathrm{L}$ $(88 \pm 5 \%, \mathrm{n}=2)$ was not significantly different $(\alpha=$ $0.05)$ than in the absence of nitrite $(90 \pm 10 \%, \mathrm{n}=2)$. $\mathrm{NH}_{2} \mathrm{OH}$ accumulation was observed during the extended lag phase suggesting initial inhibition of $\mathrm{NH}_{2} \mathrm{OH}$ oxidation by $\mathrm{NO}_{2}^{-}$(Figure 4, D1). Lower NO production was observed in the presence of added $\mathrm{NO}_{2}{ }^{-}$ (Figure 4, D3). In parallel, a substantial reduction in the fraction of cells with detectable intracellular NO was also observed, from $98.3 \pm 2.1 \%$ during exponential phase to $66.6 \pm 10.4 \%$ during stationary phase (Figure 4 , D3). sOUR values were not significantly different $(\alpha=$ $0.05)$ in the presence or absence of added $\mathrm{NO}_{2}{ }^{-}-\mathrm{N} / \mathrm{L}$ (Figure 4, D2, Figure 2, B2, respectively). Exponential phase relative mRNA concentrations of $a m o A$ and hao were statistically lower during growth in the presence of $280 \mathrm{mg} \mathrm{NO}{ }^{-}-\mathrm{N} / \mathrm{L}$ than in the absence of added nitrite (Figure 4, D4, Table 4). However, exponential phase transcription of nirK and norB was significantly higher in the presence of $280 \mathrm{mg} \mathrm{NO}{ }^{-}-\mathrm{N} / \mathrm{L}$ than in the absence of added nitrite (Figure 4, D4 and Figure 3, B4, Table 4). During stationary phase, amoA, hao, nirK and norB relative mRNA concentrations were all statistically lower in the presence of $280 \mathrm{mg} \mathrm{NO}{ }^{-}-\mathrm{N} / \mathrm{L}$ than in the absence of added nitrite (Figure 3, B4 and Figure 4, D4, Table 4).

\section{Discussion}

Functional gene transcription and $\mathrm{N}$ profiles during batch growth of $N$. europaea

In addition to its well-studied $\mathrm{NH}_{3}$ oxidation pathway, the genome of $N$. europaea contains genes coding for several denitrification steps, including $\mathrm{NO}_{2}{ }^{-}$and $\mathrm{NO}$ reduction [16]. While significant work exists on expression analysis of $a m o A$ and to an extent, hao, [17-22], quantitative transcription patterns for nirK and norB are relatively less characterized. The significance of this study therefore lies in elucidating the co-transcription patterns of amoA, hao, nirK and norB under varying degree of $\mathrm{DO}$ and $\mathrm{NO}_{2}{ }^{-}$exposure during batch growth of $N$. europaea.

The general overall reduction in amoA transcription during the stationary phase, at $\mathrm{DO}=0.5$ and $1,5 \mathrm{mg}$ $\mathrm{O}_{2} / \mathrm{L}$ (Figure 3, A4-B4), can be linked to dwindling energy resources for $N$. europaea $[15,23]$ or toxicity of accumulating $\mathrm{NO}_{2}{ }^{-}$concentrations [21]. The higher amo $A$ relative mRNA concentrations during the stationary phase at $\mathrm{DO}=3.0 \mathrm{mg} \mathrm{O} / \mathrm{L}$ were not expected and likely due to the opposing trends in exponential phase and stationary phase responses to increasing DO concentrations (Figure 3, B4-D4), as discussed below.

The retention of relatively higher amoA mRNA concentrations during stationary phase compared to those for hao, nirK and norB points to the capability of $N$. europaea to sustain and rapidly increase $\mathrm{NH}_{3}$ oxidation during a transition from a starvation state (as in stationary phase) to when $\mathrm{NH}_{3}$ becomes available. Since $\mathrm{NH}_{3}$ oxidation is the very first step in energy generation for $N$. europaea, it is indeed advantageous to retain the capability (by retaining amo $A$ mRNA) for this step to a certain extent compared to downstream steps. These results are consistent with the higher retention of amo $A$ mRNA concentrations relative to those for other genes coding for carbon dioxide fixation for growth, ion transport, electron transfer and DNA replication [23]. In fact, an actual increase in $\mathrm{NH}_{3}$ transport genes during $\mathrm{NH}_{3}$ starvation in stationary phase has also been observed [23].

The increasing trend in relative mRNA concentrations of $a m o A$ and hao and sOUR with decreasing DO 


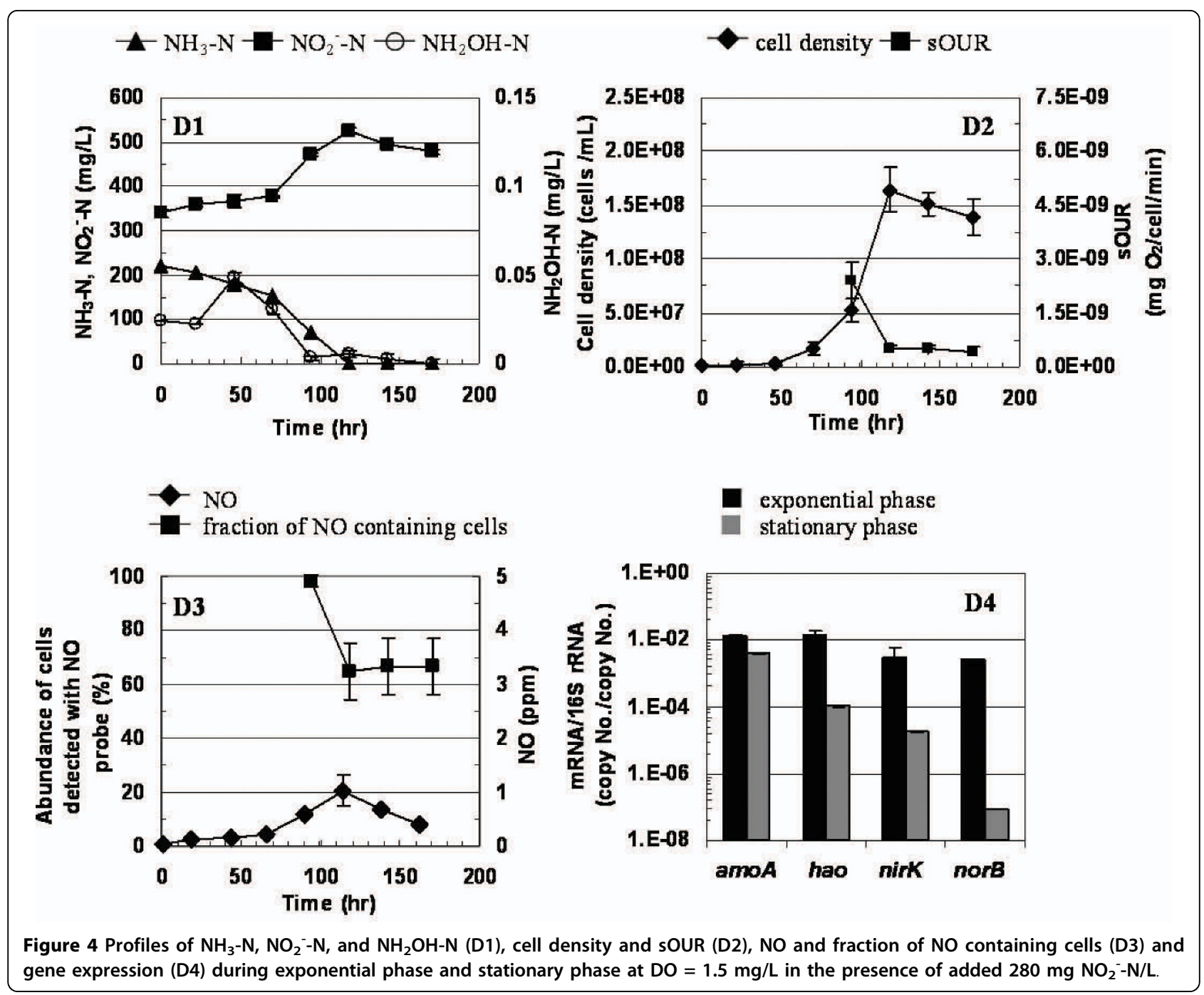

Table 4 Statistical comparison of relative mRNA concentrations and sOUR in exponential (E) and stationary (S) phase cultures grown in the presence and absence of nitrite ( $p$ values $<5.0 \times 10^{-2}$ indicate statistically significant differences)

\begin{tabular}{cccccc}
\hline Growth phase & \multicolumn{5}{c}{$\mathrm{p}=$} \\
\cline { 2 - 6 } & amoA & hao & nirK & norB & sOUR \\
\hline $\mathrm{E}$ & $7.9 \times 10^{-4}$ & $1.2 \times 10^{-3}$ & $1.3 \times 10^{-3}$ & $2.8 \times 10^{-3}$ & $7.0 \times 10^{-3}$ \\
\hline $\mathrm{S}$ & $5.1 \times 10^{-5}$ & $3.2 \times 10^{-5}$ & $3.2 \times 10^{-5}$ & $4.6 \times 10^{-5}$ & $\underline{2.0 \times 10^{-1}}$ \\
\hline
\end{tabular}

Underlined text indicates statistically similar results, bold text indicates statistical increase and regular text indicates decrease.

concentrations during exponential growth reflect a possible strategy of $N$. europaea to (partially) make up for low DO concentrations by enhancing the ammonia and hydroxylamine oxidizing machinery. One possible means to enhance substrate utilization rates at reduced DO concentrations could be to increase the capacity for oxygen transfer into the cell itself.
An alternate means could be by enhancing the ammonia or hydroxylamine oxidizing machinery (mRNA, proteins and or protein activity). The volumetric ammonia oxidation rate depends upon the mathematical product of AMO (or HAO) protein concentrations, their activity and DO concentrations (as given by the multiplicative Monod model [24]). Therefore, potentially similar ammonia oxidation rates could be maintained at lower DO concentrations by increasing the catalytic protein concentrations (or those of their precursors, such as mRNA) or activities (as measured by sOUR assays). Such an enhancement might be manifested in higher 'potential' oxygen uptake rates, measured under nonlimiting DO concentrations. Notwithstanding increased 'potential' $\mathrm{NH}_{3}$ or $\mathrm{NH}_{2} \mathrm{OH}$ oxidation activity from cells exposed to sustained lower DO concentrations, actual 'extant' activity is indeed expected to be lower under stoichiometric DO limitation, resulting in lower rates of batch cell growth or nitrite accumulation (Figure 2, A2- 
C2). Based on a recent study, $N$. europaea cultures demonstrated similar increases in $a m o A$ transcription and sOUR when subject to $\mathrm{NH}_{3}$ limitation in chemostats, relative to substrate sufficient batch cultures [15].

While it is documented that NirK is involved in $\mathrm{NH}_{3}$ oxidation by facilitating intermediate electron transport [25], the specific role of the Nor cluster in $\mathrm{NH}_{3}$ metabolism and exclusivity in $\mathrm{N}_{2} \mathrm{O}$ prodution is unclear [7]. Both NirK and Nor act upon products of upstream AMO and HAO. Thus, the lack of systematic trends in relative mRNA concentrations of nirK or norB with changing DO concentrations possibly point to less stringent regulation of these two genes during exponential growth in the overall catabolic pathways of $N$. europaea.

In contrast to exponential phase, the statistical increase in relative mRNA concentrations with increasing DO concentrations for all four genes during stationary phase is clearly intriguing. These trends highlight the impact of starvation on responses to different DO concentrations. Although the unique responses of $N$. europaea to starvation [23] and oxygen concentrations (via Fnr [26]) have been documented, the mechanisms of combined $\mathrm{NH}_{3}$ and $\mathrm{DO}$ based gene regulation in $N$. europaea are not well understood. It is well documented that ammonia oxidizing bacteria, such as $N$. europaea, are commonly subject to cycling between anoxic and oxic conditions and a wide range of $\mathrm{NH}_{3}$ concentrations in engineered and natural environments such as wastewater treatment plants or soils $[24,27,28]$. The specific responses observed herein might be part of a coordinated strategy of $N$. europaea to maintain active or latent substrate metabolic machinery to counter such varying environments and clearly merit further study.

The differences in observed transient accumulation of $\mathrm{NH}_{2} \mathrm{OH}$ could also be explained at the transcription and protein activity levels. The decrease in exponential phase hao relative mRNA concentrations with increasing DO was more rapid than for amoA (Figure 3 A4-C4). This decrease coupled with a decrease in sOUR (a composite measure of AMO and $\mathrm{HAO}$ activity) with increasing $\mathrm{DO}$, could have resulted in the observed trends in $\mathrm{NH}_{2} \mathrm{OH}$ concentrations. Although it has been shown that $N$. europaea can retain high levels of HAO protein and activity under ammonia starvation [29], the impact of DO concentrations on HAO activity has not been specifically identified. While the gene transcript data provide good insights into possible responses of $N$. europaea to different DO concentrations, protein activity data is crucial to explain profiles of intermediates such as $\mathrm{NH}_{2} \mathrm{OH}$.

The parallel profiles of exponential phase nirK relative mRNA concentrations and headspace NO concentrations at different DO concentrations (Figure 3) suggest a possible link between nirK transcription and NO generation.
However, the loss of this parallel in the presence of added $\mathrm{NO}_{2}^{-}$(higher nirK gene transcription but lower NO concentrations, Figure 4) suggests the possible presence of $\mathrm{NO}$ generation pathways that are distinct from $\mathrm{NO}_{2}{ }^{-}$reduction, as pointed out previously [26] or even post-transcriptional effects. Indeed, there is still no consensus about the source of NO produced by AOB, such as $N$. europaea, and the potential roles of nirK, hao and a multicopper oxidase of the nirK operon have all been implicated [26].

\section{Impact of exposure to high nitrite concentrations on gene transcription}

High $\mathrm{NO}_{2}{ }^{-}$concentrations have been implicated as the principal trigger for high NirK protein activity in $N$. europaea [9], which has a fundamental grounding in the similar trends observed in this study at the nirK gene mRNA level during exponential growth (Figure 4 D4). Increased nirK transcription is the result of the regulatory activity of the NsrR repressor protein, which is present in the genome of $N$. europaea [16]. NsrR is responsible for sensing $\mathrm{NO}$ and $\mathrm{NO}_{2}{ }^{-}$concentrations and is supposedly involved in the transcriptional regulation of several operons including the nirK gene cluster of $N$. europaea [9]. Although $N$. europaea contains $n o r B$, alternate pathways are possibly involved in the production of $\mathrm{N}_{2} \mathrm{O}$ [7], the increased transcription of nor $B$, shown in this study cannot be unequivocally reconciled with functional $\mathrm{N}_{2} \mathrm{O}$ production. Nevertheless, the increased transcription of both nirK and norB in response to high nitrite concentrations is in keeping with one of our initial hypotheses.

The uniformly lower transcript concentrations upon growth with added $280 \mathrm{mg} \mathrm{NO}_{2}{ }^{-}-\mathrm{N} / \mathrm{L}$ could be a result of energy resources channeled towards mitigation of nitrite toxicity rather than its utilization as an electron acceptor during stationary phase. In general, it could be argued that in response to nitrite toxicity during ammonia starvation, there is little incentive to increase transcription of putative nitrite and nitric oxide reduction pathways. However, it should be noted that the lower transcript abundance during stationary phase when grown with added $280 \mathrm{mg} \mathrm{NO}_{2}{ }^{-} \mathrm{N} / \mathrm{L}$ is in direct contrast to an increase in nirK during stationary phase, when grown without added $\mathrm{NO}_{2}{ }^{-} \mathrm{N}$ (Figure 3 B4-C4). The more gradual build-up of nitrite in the latter case could have allowed for adaptation, whereas the initial spike of $280 \mathrm{mg} \mathrm{NO}{ }_{2}^{-}-\mathrm{N} / \mathrm{L}$ might have imposed a significant toxic stress that resulted in reduced growth and different transcriptional profiles. Indeed, the toxic stress was possibly too severe at $560 \mathrm{mg} \mathrm{NO}_{2}^{-} \mathrm{N} / \mathrm{L}$, which resulted in no growth whatsoever.

Additionally, the reduction in transcript abundance of amo $A$ and hao in the presence of $\mathrm{NO}_{2}^{-}-\mathrm{N}$, did not 
parallel the relatively unchanged sOUR in the presence or absence of $\mathrm{NO}_{2}{ }^{-}-\mathrm{N}$. Given that sOUR is a measure of the sum of AMO and HAO activities, these results also suggest uncoupling of the responses at the gene transcription and post-transcriptional or translational levels (Figure 4). Responses at the protein abundance and activity levels would be needed to substantiate and provide an explanation for such uncoupling.

It should be noted that the severe impacts of added nitrite were possibly related to the application of these high nitrite concentrations at the beginning of the batch growth assays. Had the nitrite concentrations been applied during periods of relatively higher cell concentrations (during exponential or stationary phase), the impacts might have been less severe, given that the cells were already producing and responding to the increasing $\mathrm{NO}_{2}{ }^{-}-\mathrm{N}$ levels in the culture medium. Thus, in a sense, the results reported herein represent the most extreme response of $N$. europaea cultures to nitrite exposure.

\section{Conclusions}

The responses of N. europaea to cope with DO limitation and $\mathrm{NO}_{2}{ }^{-}$toxicity were wide-ranging from the gene transcription through whole cell levels. The results refuted the initial hypothesis that low DO is one of the main pre-requisite conditions for the transcription of nirK and norB genes in $N$. europaea. On the other hand, these results indeed supported our other hypothesis that higher $\mathrm{NO}_{2}{ }^{-}$concentrations constitute the principal trigger for increased relative transcription related to autotrophic denitrification reactions. The distinct responses observed during the exponential and stationary phase to both DO limitation and nitrite toxicity highlight the need to understand the specific regulatory mechanisms employed by $N$. europaea to jointly counter substrate starvation and stress.

\section{Methods}

\section{Cultivation of batch $N$. europaea cultures}

N. europaea (ATCC 19718, Manassas, VA) batch cultures were cultivated in the dark in batch bioreactors (Bellco Glass, Vineland, NJ, working volume $=4 \mathrm{~L}$, agitation speed $=200 \mathrm{rpm}$ ) in a growth medium containing $280 \mathrm{mg}-\mathrm{N} / \mathrm{L}$ and in addition (per liter): $0.2 \mathrm{~g}$ of $\mathrm{MgSO} 47 \mathrm{H}_{2} \mathrm{O}, 0.02 \mathrm{~g}$ of $\mathrm{CaCl}_{2} 2 \mathrm{H}_{2} \mathrm{O}, 0.087 \mathrm{~g}$ of $\mathrm{K}_{2} \mathrm{HPO}_{4}$, 2.52 g EPPS (3- [4-(2-Hydroxyethyl)-1-piperazine] propanesulfonic acid), $1 \mathrm{~mL}$ of $13 \%$ EDTA- $\mathrm{Fe}^{3+}, 1 \mathrm{~mL}$ of trace elements solution $\left(10 \mathrm{mg}\right.$ of $\mathrm{Na}_{2} \mathrm{MoO}_{4} 2 \mathrm{H}_{2} \mathrm{O}, 172$ mg of $\mathrm{MnCl}_{2} 4 \mathrm{H}_{2} \mathrm{O}, 10 \mathrm{mg}$ of $\mathrm{ZnSO}_{4} 7 \mathrm{H}_{2} \mathrm{O}, 0.4 \mathrm{mg}$ of $\mathrm{CoCl}_{2} 6 \mathrm{H}_{2} \mathrm{O}$, and $100 \mathrm{~mL}$ of distilled water), $0.5 \mathrm{~mL}$ of $0.5 \%$ phenol red, and $0.5 \mathrm{~mL}$ of $2 \mathrm{mM} \mathrm{CuSO}_{4} 5 \mathrm{H}_{2} \mathrm{O}$. Reactor $\mathrm{pH}$ was controlled in the range 6.8-7.4 by manual addition of pre-sterilized $40 \%$ potassium bicarbonate solution.

Batch growth experiments were conducted at three DO concentrations, $0.5 \pm 0.05,1.5 \pm 0.05$ and $3.0 \pm$ $0.05 \mathrm{mg} \mathrm{O} / 2$. Batch reactor DO was measured and controlled with a fermentation DO probe and benchtop dissolved oxygen meter and controller system (ColeParmer, Vernon Hills, IL) using a combination of filter sterilized $\left(0.2 \mu \mathrm{m}\right.$ pore size, Millipore ${ }^{\bullet}$, Ann Arbor, MI) nitrogen gas or air. In select experiments conducted at $\mathrm{DO}=1.5 \pm 0.05 \mathrm{mg} \mathrm{O} / \mathrm{L}$, the feed medium additionally contained 280, or $560 \mathrm{mg} \mathrm{NO}{ }_{2}^{-} \mathrm{N} / \mathrm{L}$ before $N$. europaea inoculation, which enabled the determination of batch growth in the presence of these high $\mathrm{NO}_{2}{ }^{-} \mathrm{-N}$ concentrations. $\mathrm{NH}_{3}$ (gas-sensing electrode, Corning, Corning, $\mathrm{NY}$ ), $\mathrm{NH}_{2} \mathrm{OH}$ [30], $\mathrm{NO}_{2}^{-}$(diazotization, [31], cell concentration (direct counting) and gaseous NO (chemiluminescence, CLD-64, Ecophysics, Ann Arbor, MI) were measured once a day during the batch growth profile. All batch growth experiments were conducted in duplicate.

\section{Detection of intracellular and extracellular nitric oxide}

Intracellular NO presence was determined by staining with 4-amino-5-methylamino-2',7'-difluorofluorescein diacetate (Molecular Probes, Eugene, OR) for $30 \mathrm{~min}$ in the absence of light. Stained cells were washed twice with sterile $\mathrm{NH}_{3}$-free medium and quantified immediately with epifluorescence microscopy (Nikon ECLIPSE $80 \mathrm{i}$ ) using a minimum of 10 randomly-chosen microscopic fields (each $0.30 \times 0.22 \mathrm{~mm}^{2}$ ). NO was specifically the focus of gaseous bulk phase and intra-cellular measurements since it is the direct product of nitrite reduction, the main focus of this study. Additionally, the presence of NO inside $N$. europaea cells strongly implicates its direct production by the cells themselves rather than by extracellular abiotic reactions. In contrast to $\mathrm{NO}$, there is currently no method that allows detection of intracellular $\mathrm{N}_{2} \mathrm{O}$. Therefore, $\mathrm{N}_{2} \mathrm{O}$ data was not included in bulk or intracellular measurements.

\section{Respirometry-based biokinetic monitoring}

The 'potential' maximum biokinetic rates of $\mathrm{NH}_{3}$ oxidation were determined using a short-term (lasting approximately $30 \mathrm{~min}$ ) batch respirometric assay [32]. The term 'potential' describes non-limiting $\mathrm{NH}_{3}$ (initial concentration of $50 \mathrm{mg}-\mathrm{N} / \mathrm{L}$ ) and oxygen concentrations (supersaturated initial concentration of approximately $40 \mathrm{mg} \mathrm{O}_{2} / \mathrm{L}$, shown previously to be non-inhibitory to $\mathrm{NH}_{3}$ oxidation [33]). Maximum $\mathrm{NH}_{3}$ oxidation activity per cell was expressed as the specific oxygen uptake rate, sOUR and was calculated by dividing the slope of the respirograms (DO vs time) by the cell concentration. 


\section{RNA extraction and purification}

$40 \mathrm{ml}$ cell suspensions were collected and immediately centrifuged at $4{ }^{\circ} \mathrm{C}$ and $5000 * \mathrm{~g}$ for $10 \mathrm{~min}$. The resulting cell-pellets were resuspended and lysed in $1 \mathrm{~mL}$ TRIzol $^{\circ}$ solution (Invitrogen, Carlsbad, CA). RNA was isolated from lysed cell pellets using the TRIzol ${ }^{\circ}$ RNA isolation protocol (Invitrogen). Subsequent DNA removal and reverse transcription was performed using the QuantiTect $^{\ominus}$ Reverse Transcriptase kit (Qiagen, Valencia, CA).

\section{Functional gene transcription}

Transcript abundance of $a m o A$, hao, nirK and norB was quantified by real-time reverse-transcriptase polymerase chain reaction (q-RT-PCR) using previously documented and newly designed primer sets (Table 1). Additional primers for conventional end-point PCR were also designed for hao, nirK and nor $\mathrm{B}$ and used for preparing standard curves for q-RT-PCR (Table 1). Transcription of functional genes was normalized to $16 \mathrm{~S}$ rRNA concentrations quantified using primers EUBF and EUBR [34]. q-RT-PCR and endpoint PCR were performed in duplicate on an iCycler iQ ${ }^{\mathrm{m}} 5$ (Bio-Rad Laboratories, Hercules, CA). A no-template-control was included for each set of PCR and q-RT-PCR reactions. Standard curves for q-RT-PCR consisted of six decimal dilutions of the respective plasmid DNA (corresponding to the four functional genes), containing a given endpoint PCR product. Plasmid concentrations were quantified (Cary 50 UV-Vis spectrophotometer, Varian, Palo Alto, CA) and translated to copy number assuming $660 \mathrm{Da}$ per base pair of double-stranded DNA [35]. Transcript abundance was determined from samples obtained during exponential phase. For exponential phase cultures, sampling time points were $70 \mathrm{hr}, 45 \mathrm{hr}$, and $52 \mathrm{hr}$ for DO concentrations of $0.5,1.5$ and $3 \mathrm{mg} / \mathrm{L}$, respectively, and corresponded to similar cell densities (Figure 3, A4C4)). For stationary phase cultures, the sampling time points were $165 \mathrm{hr}, 116 \mathrm{hr}$, and $119 \mathrm{hr}$ for DO concentrations of $0.5,1.5$ and $3 \mathrm{mg} / \mathrm{L}$, respectively (Figure 3, A4-C4)). The sampling time points for exponential and stationary phase cultures, which were grown with addded $280 \mathrm{mg} \mathrm{NO}{ }^{-}-\mathrm{N} / \mathrm{L}$ were $95 \mathrm{hr}$, and $143 \mathrm{hr}$, respectively (Figure 4, D4).

\section{Acknowledgements}

This study was co-supported by the National Fish and Wildlife Foundation and the Water Environment Research Foundation.

\section{Authors' contributions}

RY performed the experiments and drafted the manuscript. KC conceived of and developed the study, helped to analyze and interpret the results and draft the manuscript. Both authors have read and approved the final manuscript.

Received: 3 September 2009 Accepted: 4 March 2010 Published: 4 March 2010
References

1. Wood PM: Nitrification as a bacterial energy source. Nitrification, Special Publications of the Society for General Microbiology Oxford: IRL PressProsser JI 1986, 20:39-62.

2. Ahn JH, Yu R, Chandran K: Distinctive microbial ecology and biokinetics of autotrophic ammonia and nitrite oxidation in a partial nitrification bioreactor. Biotechnol Bioeng 2008, 100(6):1078-1087.

3. Arp DJ, Chain PSG, Klotz MG: The impact of genome analyses on our understanding of ammonia-oxidizing bacteria. Annu Rev Microbiol 2007, 61(1)

4. Watson SW, Bock E, Harms H, Koops H-P, Hooper AB: Nitrifying Bacteria. Bergey's Manual of Systematic Bacteriology Baltimore, MD: Williams \& Wilkins 1989.

5. Hooper AB, Vannelli T, Bergmann DJ, Arciero DM: Enzymology of the oxidation of ammonia to nitrite by bacteria. Antonie van Leeuwenhoek 1997, 71:59-67.

6. Poth $\mathrm{M}$, Focht DD: $15 \mathrm{~N}$ Kinetic analysis of $\mathrm{N}_{2} \mathrm{O}$ production by Nitrosomonas europaea: An examination of nitrifier denitrification. Appl Environ Microbiol 1985, 49(5):1134-1141.

7. Beaumont HJE, van Schooten B, Lens SI, Westerhoff HV, van Spanning RJM: Nitrosomonas europaea expresses a nitric oxide reductase during nitrification. J Bacteriol 2004, 186(13):4417-4421.

8. Schmidt I, Steenbakkers PJM, op den Camp HJM, Schmidt K, Jetten MSM: Physiologic and proteomic evidence for a role of nitric oxide in biofilm formation by Nitrosomonas europaea and other ammonia oxidizers. J Bacteriol 2004, 186:2781-2788.

9. Beaumont HJE, Lens SI, Reijinders WNM, Westerhoff HV van Spanning RJM: Expression of nitrite reductase in Nitrosomonas europaea involves NsrR, a novel nitrite-sensitive transcription repressor. Mol Microbiol 2004, 54(1).

10. Bock E: Nitrogen loss caused by denitrifying Nitrosomonas cells using ammonium or hydrogen as electron donors and nitrite as electron acceptor. Arch Microbiol 1995, 163:16-20.

11. Kester RA, de Boer W, Laanbroek HJ: Production of $\mathrm{NO}$ and $\mathrm{N}_{2} \mathrm{O}$ by pure cultures of nitrifying and denitrifying bacteria during changes in aeration. Appl Environ Microbiol 1997, 63:3872-3877.

12. Stein LY, Arp DJ: Ammonium limitation results in the loss of ammoniaoxidizing activity in Nitrosomonas europaea. Appl Environ Microbiol 1998, 64(4):1514-1521

13. Korner H, Zumft WG: Expression of denitrification enzymes in response to the dissolved oxygen level and respiratory substrate in continuous culture of Pseudomonas stutzeri. Appl Environ Microbiol 1989, 55:1670-1676.

14. Chandran K, Hu Z, Smets BF: A critical comparison of extant batch respirometric and substrate depletion assays for estimation of nitrification biokinetics. Biotechnol Bioeng 2008, 101(1):62-72.

15. Chandran K, Love NG: Physiological state, growth mode, and oxidative stress play a role in Cd(II)-mediated inhibition of Nitrosomonas europaea 19718. Appl Environ Microbiol 2008, 74(8):2447-2453.

16. Chain $P$, Lamerdin J, Larimer F, Regala W, Lao V, Land M, Hauser L, Hooper A, Klotz M, Norton J, et al: Complete genome sequence of the ammonia-oxidizing bacterium and obligate chemolithoautotroph Nitrosomonas europaea. J Bacteriol 2003, 185(9):2759-2773.

17. Hommes NG, Sayavedra-Soto L, Arp DJ: Mutagenesis and expression of amo, which codes for ammonia monooxygenase in Nitrosomonas europaea. J Bacteriol 1998, 180(13):3353-3359.

18. Stein LY, Arp DJ: Loss of ammonia monooxygenase activity in Nitrosomonas europaea upon exposure to nitrite. Appl Environ Microbiol 1998, 64(10):4098-4102.

19. Hommes NG, Sayavedra-Soto L, Arp DJ: Transcript analysis of multiple copies of amo (encoding ammonia monooxygenase) and hao (encoding hydroxylamine oxidoreductase) in Nitrosomonas europaea. J Bacteriol 2001, 183(3):1096-1100.

20. Ensign SA, Hyman MR, Arp DJ: In vitro activation of ammonia monooxygenase from Nitrosomonas europaea by copper. J Bacteriol 1993, 175(7):1971-1980.

21. Stein LY, Sayavedra-Soto LA, Hommes NG, Arp DJ: Differential regulation of $a m o A$ and $a m o B$ gene copies in Nitrosomonas europaea. FEMS Microbiol Lett 2000, 192(2):163-168.

22. Sayavedra-Soto LA, Hommes NG, Russell SA, Arp DJ: Induction of ammonia monooxygenase and hydroxylamine oxidoreductase mRNAs by ammonium in Nitrosomonas europaea. Mol Microbiol 1996, 20(3):541-548. 
23. Wei X, Yan T, Hommes NG, Liu X, Wu L, McAlvin C, Klotz MG, SayavedraSoto LA, Zhou J, Arp DJ: Transcript profiles of Nitrosomonas europaea during growth and upon deprivation of ammonia and carbonate. FEMS Microbiol Lett 2006, 257(1):76-83.

24. Grady CPLJ, Daigger GT, Lim HC: Biological Wastewater Treatment. New York: Marcel Dekker, 21999.

25. Cantera J, Stein L: Role of nitrite reductase in the ammonia-oxidizing pathway of Nitrosomonas europaea. Arch Microbiol 2007, 188(4):349-354.

26. Beaumont HJE, Hommes NG, Sayavedra-Soto LA, Arp DJ, Arciero DM, Hooper AB, Westerhoff HV, van Spanning RJM: Nitrite reductase of Nitrosomonas europaea is not essential for production of gaseous nitrogen oxides and confers tolerance to nitrite. J Bacteriol 2002, 184(9):2557-2560.

27. Davidson EA, Matson PA, Vitousek PM, Riley R, Dunkin K, Garcia-Mendez G, Maass JM: Processes Regulating soil emissions of $\mathrm{NO}$ and $\mathrm{N}_{2} \mathrm{O}$ in a seasonally dry tropical forest. Ecology 1993, 74(1):130-139.

28. Wrage N, Velthof GL, Laanbroek HJ, Oenema O: Nitrous oxide production in grassland soils: assessing the contribution of nitrifier denitrification. Soil Biol Biochem 2004, 36(2):229-236.

29. Nejidat A, Shmuely H, Abeliovich A: Effect of ammonia starvation on hydroxylamine oxidoreductase activity of Nitrosomonas europaea. J Biochem (Tokyo) 1997, 121(5):957-960.

30. Frear DS, Burrell RC: Spectrophotometric method for determining hydroxylamine reductase activity in higher plants. Anal Chem 1955, 27:1664-1665

31. Eaton AD, Clesceri LS, Greenberg AE, eds: Standard Methods for the Examination of Water and Wastewater. Washington DC: APHA, AWWA and WEF, 212005.

32. Chandran K, Smets BF: Optimizing experimental design to estimate ammonia and nitrite oxidation biokinetic parameters from batch respirograms. Wat Res 2005, 39(20):4969-4978.

33. Chandran K: Biokinetic characterization of ammonia and nitrite oxidation by a mixed nitrifying culture using extant respirometry. Ph. $D$. Dissertation Storrs: University of Connecticut 1999.

34. Nadkarni MA, Martin FE, Jacques NA, Hunter N: Determination of bacterial load by real-time PCR using a broad-range (universal) probe and primers set. Microbiol 2002, 148(1):257-266.

35. Madigan MT, Martinko JM: Brock Biology of Microorganisms. Upper Saddle River, NJ: Prentice Hall, 112006

36. Holmes AJ, Costello A, Lidstrom ME, Murrell JC: Evidence that particulate methane monooxygenase and ammonia monooxygenase may be evolutionarily related. FEMS Microbiol Lett 1995, 132(3):203-208.

37. Okano $Y$, Hristova $K R$, Leutenegger $C M$, Jackson $L E$, Denison RF, Gebreyesus B, Lebauer D, Scow KM: Application of real-time PCR to study effects of ammonium on population size of ammonia-oxidizing bacteria in soil. Appl Environ Microbiol 2004, 70(2):1008-1016.

38. Yu R, Kampschreur MJ, van Loosdrecht MCM, Chandran K: Molecular mechanisms and specific directionality in autotrophic nitrous oxide and nitric oxide production in response to transient anoxia. Environ Sci Technol 2010, 44(4):1313-1319.

39. Moyer CL, Dobbs FC, Karl DM: Estimation of diversity and community structure through restriction fragment length polymorphism distribution analysis of bacterial 16S rRNA genes from a microbial mat at an active, hydrothermal vent system, Loihi Seamount, Hawaii. Appl Environ Microbiol 1994, 60(3):871-879.

doi:10.1186/1471-2180-10-70

Cite this article as: $Y u$ and Chandran: Strategies of Nitrosomonas europaea 19718 to counter low dissolved oxygen and high nitrite concentrations. BMC Microbiology 2010 10:70

\section{Submit your next manuscript to BioMed Central and take full advantage of:}

- Convenient online submission

- Thorough peer review

- No space constraints or color figure charges

- Immediate publication on acceptance

- Inclusion in PubMed, CAS, Scopus and Google Scholar

- Research which is freely available for redistribution

Submit your manuscript at www.biomedcentral.com/submit
Biomed Central 